\title{
George Blanchard Lucas, 1915 to 1997
}

\author{
Arthur Kelman and Robert Aycock
}

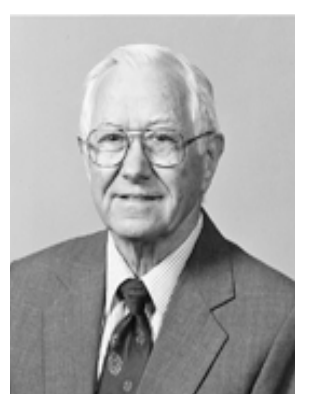

George B. Lucas, an international authority on the diseases of tobacco and emeritus professor of plant pathology at North Carolina State University, Raleigh, died after a short illness on 11 May 1997 at the age of 82. He was born in Phillipsburg, PA, on 15 March 1915, a son of the late Ruben and Rebekah Lucas. George attended the National Farm School in Doyleston, PA, from 1932 to 1935. In June 1940, George received a B.S. degree in botany from Pennsylvania State University, University Park, where he also earned a Phi Beta Kappa key and his letter in football. A graduate research assistantship in plant pathology at Louisiana State University, Baton Rouge, enabled him to complete a M.S. degree in 1942 under the direction of Irwin L. Forbes and John P. Chilton.

In November 1942, George enlisted in the Navy and attended a Naval Officer Training School at Northwestern University, Chicago. He was commissioned an ensign upon completion of the program in 1943. Assigned to the U.S.S. Tern, a sea-going tug, he left California in May 1943 for duty in Pearl Harbor, HI. In June 1944, the Tern undertook support operations for combat forces in the Gilbert and the Admiralty islands near New Guinea and continued in a variety of assignments in the South Pacific until April 1945. Mustered out of the Navy in May 1945, George returned to graduate studies at Louisiana State University and was awarded his Ph.D. degree in 1946. His first position was as an assistant professor in the Department of Plant Pathology at North Carolina State University. Initially, George was assigned to the Tobacco Research Station in Oxford, NC. In 1951, he was transferred to the main campus of North Carolina State University, remaining there until his retirement in 1980. His primary research assignment involved studies on the biology and control of the major fungal diseases of tobacco including blue mold, black shank, and leaf spot diseases. George was also a coinvestigator on the research study that provided the first conclusive evidence that root-knot nematodes (Meloidogyne species) enhanced severity of bacterial wilt of tobacco (caused by Pseudomonas solanacearum).

George was author or co-author of more than 100 research papers. His best known publication is the comprehensive text Diseases of Tobacco that was first published in 1958. This authoritative book quickly became one of the most widely used references on the diseases of this crop and has been issued in two later editions. George co-authored, with C. L. Campbell and L. T. Lucas, a well-written introductory text, Plant Diseases, Identification and Management, which is in a second edition and currently used in a number of 2-year agricultural short-course programs at land grant universities. George also co-authored, with D. Shew, the Compendium of Tobacco Diseases, published by The American Phytopathological Society (APS). George greatly enjoyed teaching and, for many years, taught an introductory course on plant diseases to students enrolled in the Two-Year Agricultural Institute Program at North Carolina State University. As a devoted member of the
Fairmont United Methodist Church in Raleigh, George taught the Aldersgate Class in Sunday School on a regular basis.

Among other professional assignments, George served as president of the Southern Division of APS, councilor of the Southern Division of APS, and an associate editor of Phytopathology. George and several colleagues established a consulting company (Biological Consulting Associates) that provided advice on disease control for several companies engaged in tobacco production in the United States and other countries. He served as president of the company and, in the course of his assignments, traveled widely in Central and South America.

While in graduate school in 1940, George married Betty Boyd whom he had met while they were undergraduates at Pennsylvania State University. Ensign Lucas promised Betty that he would write to her every other day while he was away from home in the service. George kept his promise faithfully, and Betty filed all of his 342 letters from 1943 to 1945 . As a memorial to Betty who died at the age of 29 after a short illness, George edited these letters intermittently over many years in the hopes that they would eventually be published. In 1996, the Naval Institute Press published his book Every Other Day that was based on this unique collection of letters. The letters were romantic, whimsical, humorous, and sometimes reflected frustration, but were always full of hope for the future. They provide an insightful recording of his experiences as a naval officer in the Pacific during a period of intense conflict.

"Luke," as he was affectionately known by his friends, was a warm, gregarious individual with an engaging sense of humor and an uncommon skill as a writer of prose and poetry. He loved music, particularly folk songs, which he enjoyed singing. For many years, Luke took great pleasure in growing roses, and several of his best specimens won awards in local garden shows. Luke had a very wide circle of friends in his community and among tobacco researchers both nationally and internationally. His unflagging optimism and bright spirit will be missed by all who looked forward to his enthusiastic participation in any meeting or social gathering; George always enlivened such occasions with his often humorous comments and penetrating questions.

After the early death of his wife, Betty, in 1950, George was left to raise his three young sons, Irvin $\left(4^{1} \frac{1}{2}\right.$ years old) and the twins, Glen and Guy (18 months old). In 1955, George married Vernelle Vaughan Byrd, who had two sons by a previous marriage, Woodson and Lee; later, they had two children of their own, Candace and George Blanchard, Jr. Six years after Vernelle passed away, George married Mary Elizabeth Wood, the mother of three adult children, Beth Legrand, Jane Youngblood, and Bob Wood, Jr. George is survived by his wife, Mary Elizabeth Lucas; a sister, Alzene Lucas of Phillipsburg, PA; his five children and five stepchildren; their spouses; and 18 grandchildren. In his memory, colleagues and friends have established "The George B. Lucas Scholarship Fund" for graduate students in plant pathology at North Carolina State University (North Carolina Agricultural Foundation, NCSU, Box 76454, Raleigh, NC 27695-7645).

Publication no. P-1997-1029-030 